\title{
EVALUATION OF THE SURFACE WATER QUALITY OF THE TURUNCHUK RIVER FOR DRIP IRRIGATION SYSTEMS
}

\author{
A.P. Blazhko, Associate Professor \\ Odessa State Academy of Civil Engineering and Architecture \\ blazhko49@gmail.com, ORCID: 0000-0001-7951-8811
}

\begin{abstract}
The quality assessment of the surface waters of the Turunchuk river was carried out by the average annual values of hydrochemical indicators for $2006 . .2016$ for the drip irrigation systems for agronomic (for the risk of irrigation salinization, saltification, alkalization of the soil and the toxic effect of irrigation water on plants); environmental (on the content of plant nutrients); ecological hygienic (according to the content in water of mineral nitrogen, trace elements and the amount of oxygen consumed during 5 days of incubation); environmental toxicological (on the content of heavy metals, petroleum products, synthetic surfactants) and technical (on water salinity, of total hardness and suspended solids, manganese, iron content and hydrogen activity) criteria.

It has been established by researches that according to the danger of irrigation salinization of soils, irrigation waters of such quality correspond to class I water quality and are suitable for the drip irrigation systems without restrictions. In addition, based on a comprehensive assessment of indicators $\mathrm{pH}$, toxic alkalinity, alkalinity from normal carbonates, the ratio of the sum of alkaline captions of sodium and potassium to the sum of all captions, taking into account the particle size distribution of the soil and their buffering capacity), irrigation waters correspond to class I water quality and are suitable for the drip irrigation systems without restrictions. According to the environmental criteria, the irrigation waters of the Turunchuk river for the content of trace elements and heavy metals correspond to class I water quality and cannot have a negative impact on the soil and agricultural crops.

Evaluation of the suitability of water according to the degree of its influence on the elements of the drip irrigation systems was made taking into account the possibility of preventing its corrosion, silting, bio-growth, which occurs as a result of the gradual accumulation at suspended sediments of mineral and organic origin, salt deposits and microorganisms vital products. It has been found by the research that surface waters of the Turunchuk river according to the degree of influence on the nodes and elements of the pipeline network are suitable for the drip irrigation without restrictions.
\end{abstract}

Key words: drip irrigation; agronomical, ecological, technical criteria of water quality.

Foreword. Today, the main efforts in irrigation farming in Ukraine are aimed at reconstruction and modernization of irrigated systems, increasing of irrigation efficiency, water conservation, and environmental protection. Drip irrigation is one of the solutions of the tasks. It is the most important part of the modern highly intensive technologies of growing gardens, berries, vineyards, seed-plots, vegetables, potatoes, and a number of other technical and cultivated crops, because due to the technological possibilities of this method (discrete water supply and dissolved fertilizers in it trace elements in the feed zone and each plant in strict accordance with its needs), conditions are created for maximizing the potential of plant productivity. One of the conditions for the successful application of drip irrigation is the quality of irrigation water, which determines the safe impact on soils and the environment, and also ensures the reliable functioning of drip irrigation systems (DIS). Water quality is the main criterion to be taken into account at the design stage and by which is possible to predict the lifetime of the drip irrigation system [1, p. 6, 18].

The analysis of the latest sources of researches and publications. As the result of the analysis of the scientific publications on the subject of the research, it was found out that active study of drip 
irrigation systems started in the late 70's of the last century. The leading institutions at that time were the Rainwater Cleaning and Protection Laboratory NWO «Raduga», the Water Treatment Department of the Central Research Institute for the multipurpose water Use of Water Resources (Moldova), the Laboratory of Drop and infiltration irrigation of the Ukrdividzhdoshp Institute, the National University of Water Management and Environmental Management, the Institute of Water Engineers, the Chisinau Laboratory of Technical means and technology of Drop Irrigation UkrNDGiM and others. Precisely in these institutions were conducted their researches such scientists as: M.G. Zhurba, I.I. Naumenko, M.I. Romashchenko, A.T. Kalienikov, A.M. Sydorenko, M.O. Turcheniuk, L.P. Fadieieva, Z.R. Malanchuk, A.P. Maltseva, I.V. Drahomyretskyi, Y.L. Tenenbaum, T.I. Khudaikulov and others [2]. A team of scientists chaired by M.G. Zhurba on the basis of experimental and theoretical researches which have been carried out during 1977...1990, determined the role of quality of irrigation water in the changes of flow-pressure characteristics and properties of technical elements of drip irrigation systems during their operation.

The authors have developed methods for the regulation of the quality of irrigation water, the classification of water sources for drip irrigation systems and the list of items of water treatment equipment and buildings $[3,4]$.

Scientists of the Institute of Hydrotechnics and Melioration of the National Academy of Sciences of Ukraine (1986...1995) under the charge of M.I. Romashchenko have studied the influence of the quality of irrigation water on the working efficiency of micro-flows of drip irrigation systems. According to the results of the scientific work, methodological guidelines on the choice of technological schemes and means of water preparation in micro-irradiation systems, which establish common requirements for the quality of irrigation water, the choice of technological schemes and technical means of water preparation, have been developed. These requirements are extended to the design, construction and operation of micro-irrigation systems.

Over the past few years, the research network of the Institute of Water Problems and Melioration of the National Academy of Sciences of Ukraine, which includes research stations and demonstration fields, makes it possible to carry out tests and improvements of scientific developments and the wide introduction of the best practices of new achievements of microirrigation ameliorative science. The works of scientists such as: M.I. Romashchenko, A.M. Rokochynskoho, A.P. Shatkovskoho, S.V. Riabkova, V.M. Koriunenka, A.G. Matviiets, R. Kupedinova, F. Melnychuka, YU. Cherevychnoho, L. Semenko and others are dedicated to the development and improvement of micro-irradiation regimes and the influence of the quality of irrigation water on the soils of the steppe and forest-steppe territory of Ukraine [5-8]. However, there are no scientific publications as to the assessment of surface water quality in the watercollecting area of the Turunchuk River for drip irrigation, which determines the relevance of the selected research subject.

The formulation of the problem. The purpose of the research is evaluation of the surface water of the Turunchuk River for drip irrigation systems. In order to achieve this goal, the following tasks were defined: water quality assessment according to agronomic, ecological, ecologicalhygienic, ecological-toxicological and technical criteria.

The object and methods of the research. The object of the study are the surface waters of the Turunchuk River, which formed approximately between 1780 and 1785 through the branching of the navigable channel of the Dniester at the 146th kilometer from the frith near the village of Chobruky, the Republic of Moldova (Transnistria). Then it flows near the villages of Glenn, Nezavertaylovka and again falls into the Dniester at the 20th kilometer from the frith near the town of Bilyaivka. Thanks to the sandy low ridge washed in by water, the Turunchuk was separated from the Belaya Lake and falls directly into the Dniester. The Turunchuk takes about $60 \%$ of the water of the Dniester River. Most part of the shores are cuspate and clayey, they are covered with willow shrub, osier and wild-growing herbs. On the banks of the Turunchuk there is the Kuchurgan water storage drainage and the system of the lakes Bil, Butryne and Tudorovy. The length of the Turunchuk is $60 \mathrm{~km}$, its average width is about $30 \mathrm{~m}$, and only on tight corners (meanders) can increase to $50 \ldots 60 \mathrm{~m}$, the average depth is $-6 \mathrm{~m}$ [9].

The results of hydro chemical observations of water quality during $2006 \ldots 2016$ are presented 
in the paper, which were provided by the Department of Environment and Natural Resources of Odessa Regional State Administration and the State Agency «Odessa Regional Laboratory Center MoH of Ukraine» $[10,11]$. Water specimens were selected every three months four times a year. Organization of monitoring of the quality of river waters, as well as the list of controlled hydro chemical indicators, correspond to the governing documents [12,13].

The presentation of the main material and the substantiation of the results of the research. Agronomic criteria for water availability for drip irrigation establishes DSTU 7591: 2014 «Irrigation. Water quality for drop irrigation systems. Agronomic, Environmental and Technical Criteria» [14], according to which the regulation of the quality of irrigation water is based on the indicator of the total concentration of toxic ions (in chlorine equivalents), taking into account the granulometric composition of soils.

During the assessment of the quality of irrigation water, three classes of its suitability are distinguished: $1^{\text {st }}$ class - Suitable, $2^{\text {nd }}$ class - Limited fit, $3^{\text {rd }}-$ Unsuitable. Irrigated water of the $1^{\text {st }}$ class is suitable for unrestricted irrigation. $2^{\text {nd }}$ class water is used provided the mandatory application of a set of measures to prevent soil degradation or improvement of water to the indicators of $1^{\text {st }}$ class Irrigated water of $3^{\text {rd }}$ class - water, the parameters of which exceed the values set for irrigation water of the $2^{\text {nd }}$ class, is not suitable for irrigation without the prior improvement of its composition.

The assessment of surface water quality due to the danger of irrigation salinization of soils. First of all, to determine the content of toxic ions, all major ions in $\mathrm{megv} / \mathrm{dm}^{3}$ should be bound to hypothetical molecules of toxic and neutral salts according to the scheme [14]. The assessment of surface water quality is based on the index of toxic ions reflected in the chloride-ion equivalents $\left(e \mathrm{Cl}^{-}\right), \mathrm{megv} / \mathrm{dm}^{3}$, taking into account the granulometric composition of the soils by the formula:

$$
e \mathrm{Cl}^{- \text {toxic }}=\mathrm{Cl}^{-}+0,2 \mathrm{SO}_{4}^{2-\text { toxic }}+0,4 \mathrm{HCO}_{3}^{- \text {toxic }}+10 \mathrm{CO}_{3}^{2-\text { toxic }},
$$

where $e \mathrm{Cl}^{\text {toxic }}$ - amount of toxic salts in chlorine equivalents, $\mathrm{mekv} / \mathrm{dm}^{3} ; \mathrm{Cl}^{-}$- amount of chlorides, megv/ $\mathrm{dm}^{3} ; \mathrm{SO}_{4}^{2-t o x i c}$ - amount of toxic sulfates, $m e g v / \mathrm{dm}^{3} ; \mathrm{HCO}_{3}^{\text {-toxic }}$ - the amount toxic hydro carbonates, megv/ $\mathrm{dm}^{3} ; \mathrm{CO}_{3}^{2-t o x i c}$ - amount of toxic carbonates, megv/ $\mathrm{dm}^{3}$.

The results of the quality of surface water assessment due to the danger of irrigation solemnization of soils are given in Table. 1.

Table 1 - The assessment of the quality of irrigation water of the Turunchuk River for danger

Secondary soil solemnization for 2006...2016

\begin{tabular}{|c|c|c|c|c|c|c|c|c|c|c|c|}
\hline \multirow{2}{*}{ Indicators } & \multicolumn{10}{|c|}{ Years of research } \\
\cline { 2 - 13 } & 2006 & 2007 & 2008 & 2009 & 2010 & 2011 & 2012 & 2013 & 2014 & 2015 & 2016 \\
\hline $\begin{array}{c}e C l^{-t o x i c} \\
m e g \nu / m^{3}\end{array}$ & 2,83 & 2,23 & 1,65 & 1,65 & 2,83 & 2,11 & 1,75 & 4,11 & 4,11 & 1,89 & 1,69 \\
\hline $\begin{array}{c}\text { Water } \\
\text { quality class }\end{array}$ & $\mathrm{I}$ & $\mathrm{I}$ & $\mathrm{I}$ & $\mathrm{I}$ & $\mathrm{I}$ & $\mathrm{I}$ & $\mathrm{I}$ & $\mathrm{I}$ & $\mathrm{I}$ & $\mathrm{I}$ & $\mathrm{I}$ \\
\hline
\end{tabular}

The analysis of the table material shows that the concentration of toxic salts in the equivalents of chlorine in the water of Turunchchuk varied from 1.65 to $4.11 \mathrm{megv} / \mathrm{dm}^{3}$ (the upper limit for Ist class is $-5.0 \mathrm{megv} / \mathrm{dm}^{3}$ ), that is, surface water, due to the danger of irrigation salinisation of soils, is suitable for micro-irradiation without Limits and correspond to Ist Class of water quality [14].

The assessment of the quality of surface water due to the risk of soil degradation. Conducted on the basis of complex evaluation of the hydrogen index $(\mathrm{pH})$, toxic alkalinity $\left(\mathrm{HCO}_{3}^{-}-\mathrm{Ca}^{2+}\right), \mathrm{megv} / \mathrm{dm}^{3}$ and alkalinity from normal carbonates $\left(\mathrm{CO}_{3}^{2-}\right) \mathrm{megv} / \mathrm{dm}^{3}$. And the water quality class is determined by the two worst of the three quantitative indicators [14]. 
The results of the water quality assessment of the researched water reservoir are given in Table. 2 .

Table 2 - The integral assessment of the quality of irrigation water in the Turunchuk River due to the danger of alkalization of soil in $2006 . .2016$

\begin{tabular}{|c|c|c|c|c|c|c|c|c|c|c|c|}
\hline \multirow{2}{*}{ Indicators } & \multicolumn{10}{|c|}{ Years of research } \\
\cline { 2 - 13 } & 2006 & 2007 & 2008 & 2009 & 2010 & 2011 & 2012 & 2013 & 2014 & 2015 & 2016 \\
\hline $\mathrm{pH}$, од. & 7,5 & 7,2 & 7,3 & 7,2 & 7,6 & 7,6 & 7,2 & 8,0 & 8,0 & 7,4 & 8,1 \\
\hline $\begin{array}{c}\mathrm{HCO}_{3}^{-}-\mathrm{Ca}^{2+} \\
m e g v / m^{3}\end{array}$ & 0,4 & 0,5 & 0,2 & 0,1 & 0,4 & 0,1 & 0,2 & 0,0 & 0,0 & 0,0 & 0,2 \\
\hline $\begin{array}{c}\mathrm{CO}_{3}^{2-}, \\
m e g \nu / m^{3}\end{array}$ & 0,0 & 0,0 & 0,0 & 0,0 & 0,0 & 0,03 & 0,0 & 0,2 & 0,2 & 0,0 & 0,0 \\
\hline $\begin{array}{c}\text { Water } \\
\text { quality class }\end{array}$ & $\mathrm{I}$ & $\mathrm{I}$ & $\mathrm{I}$ & $\mathrm{I}$ & $\mathrm{I}$ & $\mathrm{I}$ & $\mathrm{I}$ & $\mathrm{I}$ & $\mathrm{I}$ & $\mathrm{I}$ & $\mathrm{I}$ \\
\hline
\end{tabular}

Throughout of the research period, the $\mathrm{pH}$ value in surface waters varied from 7.2 to 8.1 units (rift for $1^{\text {st }}$ class -8.2$)$. The indicators of toxic alkalinity $\left(\mathrm{HCO}_{3}^{-}-\mathrm{Ca}^{2+}\right)$ in river waters varied within the limits of $0 \ldots 0,5 \mathrm{megv} / \mathrm{dm}^{3}$, the upper limit of the indicator of toxic alkalinity for $1^{\text {st }}$ class water quality $-2.5 \mathrm{megv} / \mathrm{dm}^{3}$. The alkalinity of normal carbonates $\left(\mathrm{CO}_{3}^{2-}\right)$ was recorded only in 2011, 2013 and 2014 in concentrations lower than the acceptable values for $1^{\text {st }}$ class of water quality $\left(0,3 \mathrm{megv} / \mathrm{dm}^{3}\right)$. Thus, the water of the river Turunchuk is assessed for the risk of soil degradation as suitable for micro-irradiation without restrictions.

The assessment of the quality of surface water due to the danger of alkalinization of soils. The surface water quality was estimated by the magnitude of the ratio (in percentages) of the sum of alkaline cations of sodium and potassium $\left(m e g v / \mathrm{dm}^{3}\right)$ to the sum of all cations $\left(m e g v / \mathrm{dm}^{3}\right)$, taking into account the main types of irrigated soils, their anti-salinity buffer and granulometric composition of soils, the excess of magnesium in irrigation water over calcium and the $1^{\text {st }}$ class water due to the risk of soil degradation [14]. The analysis of the results of the assessment of surface water quality due to the danger of soils alkalinization shows the following. The magnitude of the ratio (in percentages) of the sum of alkaline cations of sodium and potassium to the sum of all cations ( $m e g v / \mathrm{dm}^{3}$ ) in the water of the studied water reservoir varied from 18 ,2 to 35,5 percent, which corresponds to $1^{\text {st }}$ class of water quality due to the danger of soil alkalinization. Such water is not able to exert a negative influence on the soil cover and can be used for microirradiation without restrictions.

The assessment of the quality of surface water for ecological and hygienic and ecological and toxicological indicators. The assessment is carried out in order to prevent soil degradation and selfcleaning as well as deterioration of the hygienic state and food quality of agricultural products, and carry out the content of phenols, cyanides, petroleum, petroleum products and detergents [14].

Water is considered suitable for irrigation if the content of the aforementioned substances does not exceed the maximum permissible concentrations. Environmental and hygienic assessment of water was carried out only on the indicator and content of petroleum products (other indicators of water quality were not determined by subjects of eco-monitoring).Results of the assessment of surface water quality for ecological and hygienic indicators are given in Table. 3 
Table 3 - The assessment of surface water quality in the Turunchuk River according to the average annual ecological and hygienic indicators for 2006...2016

\begin{tabular}{|c|c|c|c|c|c|c|c|c|c|c|c|c|c|}
\hline \multicolumn{2}{|c|}{ Indicators } & \multicolumn{10}{|c|}{ Years of research } \\
\cline { 2 - 11 } & 2006 & 2007 & 2008 & 2009 & 2010 & 2011 & 2012 & 2013 & 2014 & 2015 & 2016 \\
\hline $\begin{array}{c}\mathrm{BCO}_{5} \\
\mathrm{mgO}_{2} / \mathrm{dm}^{3}\end{array}$ & $\begin{array}{c}\text { lac } \\
\text { actu- } \\
\text { ally }\end{array}$ & 3,9 & 3,9 & 5,4 & 3,3 & 1,7 & 2,7 & 1,6 & 1,8 & 1,8 & 3,5 & 2,4 \\
\hline $\begin{array}{c}\text { Petroleum } \\
\text { products } \\
\mathrm{mg} / \mathrm{dm}^{3}\end{array}$ & $\begin{array}{c}\text { lac } \\
\text { actu- } \\
\text { ally }\end{array}$ & 0,03 & 0,03 & 0,04 & 0,04 & 0,01 & 0,04 & 0,02 & 0,01 & 0,01 & 0,02 & 0,02 \\
\hline $\begin{array}{c}\text { Assessment of the } \\
\text { water quality }\end{array}$ & \multicolumn{10}{|c|}{0,3} \\
\hline
\end{tabular}

The analysis of the table material allows to assert that the average annual content of petroleum products and the indicator in the water of the Turunchuk River during the investigated period did not exceed the LAC. Such water is suitable for micro-irradiation without restrictions.

The assessment of surface water quality according to technical criteria. The availability of water for the degree of influence on the elements of the SSC is carried out taking into account the possibility of preventing its corrosion, immersion, clogging, biodegradation, etc., which occur as a result of the gradual accumulation of suspended sediments of mineral and organic origin, salts deposits and products of microorganism activity [14].

According to the results of the water quality assessment it is possible to certify that the values of the assessment indicators according to the technical criteria do not exceed the LAC, that is, the water of the Turunchuk River is suitable for micro-irradiation without restrictions (Table 4).

Table 4 - The assessment of availability of irrigation water in the Turunchuk River by the degree of influence on elements of systems of drip irrigation for 2006...2016

\begin{tabular}{|c|c|c|c|c|c|c|c|c|c|c|c|c|}
\hline \multirow{2}{*}{\multicolumn{2}{|c|}{ Indicators }} & \multicolumn{11}{|c|}{ Years of research } \\
\hline & & 2006 & 2007 & 2008 & 2009 & 2010 & 2011 & 2012 & 2013 & 2014 & 2015 & 2016 \\
\hline \multirow{2}{*}{$\begin{array}{l}\text { Salinity } \\
\text { level } \\
g / d m^{3}\end{array}$} & \multirow{2}{*}{$\begin{array}{c}\text { lac } \\
\begin{array}{c}\text { actu- } \\
\text { ally }\end{array}\end{array}$} & \multicolumn{11}{|c|}{ Lower than 0,50} \\
\hline & & 0,49 & 0,44 & 0,43 & 0,42 & 0,49 & 0,49 & 0,44 & 0,49 & 0,45 & 0,49 & 0,35 \\
\hline \multirow{2}{*}{$\begin{array}{l}p H, \\
\text { units }\end{array}$} & lac & \multicolumn{11}{|c|}{ from 7,0 to 8,0} \\
\hline & $\begin{array}{l}\text { actu- } \\
\text { ally }\end{array}$ & 7,5 & 7,2 & 7,3 & 7,2 & 7,6 & 7,6 & 7,2 & 8,0 & 8,0 & 7,4 & 7,9 \\
\hline \multirow{2}{*}{$\begin{array}{c}\text { Iron content } \\
\mathrm{mg} / \mathrm{dm}^{3}\end{array}$} & lac & \multicolumn{11}{|c|}{ Lower than 0,30} \\
\hline & $\begin{array}{l}\text { actu- } \\
\text { ally }\end{array}$ & 0,03 & 0,03 & 0,04 & 0,04 & 0,01 & 0,04 & 0,02 & 0,02 & 0,01 & 0,02 & 0,02 \\
\hline \multirow{2}{*}{$\begin{array}{c}\text { Manganese } \\
\text { content } \\
m g / d m^{3}\end{array}$} & lac & \multicolumn{11}{|c|}{ Lower than 0,1} \\
\hline & $\begin{array}{l}\text { actu- } \\
\text { ally }\end{array}$ & 0,0 & 0,0 & 0,0 & 0,0 & 0,0 & 0,0 & 0,0 & 0,0 & 0,0 & 0,0 & 0,0 \\
\hline \multirow{2}{*}{$\begin{array}{c}\text { Total } \\
\text { hardness } \\
m e g v / d m^{3}\end{array}$} & lac & \multicolumn{11}{|c|}{ from 9,0 to 10,0} \\
\hline & $\begin{array}{l}\text { actu- } \\
\text { ally }\end{array}$ & 5,3 & 4,8 & 4,6 & 4,5 & 5,4 & 6,3 & 5,1 & 6,5 & 6,5 & 5,6 & 5,1 \\
\hline \multirow{2}{*}{$\begin{array}{c}\text { Suspended } \\
\text { materials } \\
m g / d m^{3}\end{array}$} & lac & \multicolumn{11}{|c|}{ from 30 to 50} \\
\hline & $\begin{array}{l}\text { actu- } \\
\text { ally }\end{array}$ & 35,0 & 30,0 & 35,6 & 45,0 & 45,8 & 48,7 & 49,0 & 42,4 & 42,4 & 30,5 & 30,5 \\
\hline \multicolumn{2}{|c|}{$\begin{array}{c}\text { The water quality } \\
\text { assessment }\end{array}$} & \multicolumn{11}{|c|}{ water is suitable for micro-irradiation without restrictions } \\
\hline
\end{tabular}


The assessment of surface water quality according to environmental criteria. The assessment of the quality of natural water for drip irrigation on the content of nutrition elements of plants is carried out in order to prevent deterioration of the ecological and hygienic properties and the nutritional value of agricultural products, as well as the ecological and hygienic state of underground and surface waters [14].

The assessment of the quality of irrigation water based on the content of certain trace elements and heavy metals is carried out taking into account the priority of the indicators and the degree of danger of elements. According to the results of environmental monitoring in the Turunchuk surface waters throughout the researched period, the content of lithium, manganese, chromium $\left(\mathrm{Cr}^{3+}\right)$, chromium $\left(\mathrm{Cr}^{6+}\right)$ was not recorded. The content of the low-toxic element of aluminum was detected only in water samples of $2011\left(0,02 \mathrm{mg} / \mathrm{dm}^{3}\right)$, the maximum concentration $-0,06$ was fixed 22.04. 2011, which corresponds to the $1^{\text {st }}$ class of water quality.

The content of nickel and copper in the water of the Turunchuk River was recorded only in 2015 and 2016 on concentrations lower than the LAC. The iron content in surface waters at the average annual values throughout the research period varied within the range of $0.0 \ldots 0.19 \mathrm{mg} / \mathrm{dm}^{3}$, which corresponds to $1^{\text {st }}$ class of water quality. The content of zinc in the surface waters of Turunchuk was recorded only in 2016, with an average annual concentration of $0.01 \mathrm{mg} / \mathrm{dm}^{3}$, and a maximum value of $0,024 \mathrm{mg} / \mathrm{dm}^{3}-25.07 .2016$. The cadmium content varied from 0,0001 to $0,0003 \mathrm{mg} / \mathrm{dm}^{3}$ (LAC $\left.0,005 \mathrm{mg} / \mathrm{dm}^{3}\right)$.

Conclusions. Thus, the obtained results of the surface water quality assessment of the Turunchuk River provide an opportunity to state that there couldn't be difficult problems with the use of water of the researched water reservoir for drip irrigation. Irrigation water of such quality cannot endanger the secondary salinization, degradation, soil alkalanization, have a negative impact on crops, cause a deterioration of the ecological status and food quality of agricultural products. In addition, the degree of influence on the elements of the SKZ, irrigation water is quite suitable for micro-irradiation.

\section{References}

[1] M.I. Romashchenko, A.M. Rokochynskyi, V.M. Koriunenko, Kraplynne zroshennia: navchalnyi posibnyk, Kherson, Ukraina: OLDI-PLIuS, 2015.

[2] S.B. Usatyi, R.A. Kupiedinova, Vyprobuvannia tekhnichnykh zasobiv mikrozroshennia", [Elektronnyi resurs]. Rezhym dostupu : mivg.iwpim.com.ua/load/mivg99/99_5.pdf, Vup. 99. - pp. 44-53, 2011.

[3] M.G. Zhurba, M.H. Mykrooroshenye, Problemy kachestva vody: nauchnoe yzdanye. Moskow. Kolos, 1994.

[4] M.G. Zhurba, P.M. Novik, V.M. Moshko, Rekomendatsii po otsenke prigodnosti vodyi, vyiboru kapelnits, sredstv vodoochistki $i$ sposobov borbyi s zasoreniem polivnoy seti sistem kapelnogo orosheniya. Kishinov, Timpul, 1985.

[5] M.I. Romaschenko, T.I. Hudaykulov, "Vliyanie kachestva vodyi na rabotosposobnost mikrovodovyipuskov sistem mikroorosheniya", Vestn. agrar. Nauki pp. 54-60, 1994.

[6] M.I. Romaschenko, I.V. Dragomiretskiy, A.T. Kalenikov, T.I. Hudaykulov, Metodicheskie ukazaniya. Vyibor tehnologicheskih shem i tehnicheskih sredstv vodopodgotovki dlya sistem mikroorosheniya. K.: Goskomitet po vodnomu hozyaystvu Ukrainyi, 1995.

[7] I.I. Naumenko, A.M. Sidorenko, M.I. Romaschenko, Rekomendatsii po issledovaniyam nadyozhnosti i kontrolyu kachestva elementov sistem kapelnogo orosheniya. K.: UkrNIIGiM, 1990. 
[8] M.I. Romashchenko, A.P. Shatkovskyi, S.V. Riabkov [ta in]. Kontseptsiia rozvytku mikrozroshennia v Ukraini do 2020 roku. K.: 2012.

[9] Entsiklopediya Moldovyi ot A do Ya. MOLDOVENII Priroda i turizm. [Elektronnyiy resurs]. Rezhim dostupu: http://moldovenii.md/ru/wiki. 2002.

[10] Fondovi materialy Departamenta ekolohii ta pryrodnykh resursiv Odeskoi ODA Doslidzhennia poverkhnevykh vod Odeskoi oblasti v 2006-2015 rr.

[11] Fondovi materialy Derzhavnoi ustanovy «Odeskyi oblasnyi laboratornyi tsentr MOZ Ukrainy» / Doslidzhennia poverkhnevykh vod Odeskoi oblasti v 2016 r.

[12] Yedyne mizhvidomche kerivnytstvo po orhanizatsii ta zdiisnenniu derzhavnoho monitorynhu vod. K.: Minekoresursiv Ukrainy, 2001.

[13] GOST 17.1.2.03-90. Ohrana prirodyi. Gidrosfera. Kriterii i pokazateli kachestva vodyi dlya orosheniya. [Elektronnyiy resurs]. Rezhim dostupu: http//www/gosthelp/ru/gost.

[14] DSTU 7591 : 2014. Chynnyi vid 2014-12-02. Zroshennia. Yakist vody dlia system kraplynnoho zroshennia. Ahronomichni, ekolohichni ta tekhnichni kryterii. K.: Minekonomrozvytku Ukrainy, 2015.

\title{
ОЦНЮВАННЯ ЯКОСТІ ПОВЕРХНЕВИХ ВОД РІЧКИ ТУРУНЧУК ДЛЯ СИСТЕМ КРАПЛИННОГО ЗРОШЕННЯ
}

\author{
А.П. Блажко, доцент \\ Одеська державна академія будівництва та архітектури \\ blazhko49@gmail.com, ORCID: 0000-0001-7951-8811
}

\begin{abstract}
Анотація. Виконано оцінювання якості поверхневих вод річки Турунчук за середньорічними значеннями гідрохімічних показників впродовж 2006...2016 pр. для систем краплинного зрошення за агрономічними (небезпека іригаційного засолення, осолонцювання, підлуження грунту і токсичного впливу зрошувальної води на рослини); екологічними (вміст елементів живлення рослин); еколого-гігієнічними (вміст у воді мінерального азоту, мікроелементів і кількості кисню, спожитого за 5 діб інкубації); екологотоксикологічними (вміст важких металів, нафтопродуктів, синтетичних поверхнево-активних речовин) та технічними (мінералізація води, загальної жорсткості і вмісту у воді завислих речовин, марганцю, заліза та активності водню) критеріями.

Дослідженнями встановлено, що за небезпекою іригаційного засолення грунтів зрошувальні води такої якості відповідають I класу якості води і придатні для систем краплинного зрошення без обмежень. Крім того, на основі комплексної оцінки показників (рН, токсичної лужності, лужності від нормальних карбонатів, величини відношення суми лужних катіонів натрію і калію до суми усіх катіонів, з урахуванням гранулометричного складу грунтів і їх буферності) зрошувальні води відповідають I класу якості води і придатні для систем краплинного зрошення без обмежень. За екологічними критеріями зрошувальні води Турунчука щодо вмісту мікроелементів і важких металів відповідають I класу якості води і не можуть справляти негативний вплив на грунти і сільськогосподарські культури.

Оцінювання придатності води за ступенем впливу іiї на елементи систем краплинного зрошення виконано з урахуванням запобігання їх корозії, замуленню, біозарастанню, що відбуваються в результаті поступового накопичення в них зважених наносів мінерального i органічного походження, відкладів солей і продуктів життєдіяльності мікроорганізмів. Дослідженням встановлено, що поверхневі води р. Турунчук за ступенем впливу їх на вузли i елементи трубопровідної мережі придатні для краплинного зрошення без обмежень.

Ключові слова: краплинне зрошення, агрономічні, екологічні, технічні критерії якості води.
\end{abstract}




\title{
ОЦЕНИВАНИЕ КАЧЕСТВА ПОВЕРХНОСТНЫХ ВОД РЕКИ ТУРУНЧУК ДЛЯ СИСТЕМ КАПЕЛЬНОГО ОРОШЕНИЯ
}

\author{
А.П. Блажко, доцент, \\ Одесская государственная академия строительства и архитектуры \\ blazhko49@gmail.com, ORCID: 0000-0001-7951-8811
}

\begin{abstract}
Аннотация. Выполнено оценивание качества поверхностных вод реки Турунчук по среднегодовым значениям гидрохимических показателей за 2006..2016 гг. для систем капельного орошения по агрономическим (по опасности ирригационного засоления, осолонцевания, подщелачивания почв и токсического влияния оросительной воды на растения); экологическим (по содержанию элементов питания растений); экологогигиеническим (по содержанию в воде минерального азота, микроэлементов и количеству кислорода, потребленного за 5 суток инкубации); эколого-токсикологическим (по содержанию тяжелых металлов, нефтепродуктов, синтетических поверхностно-активных веществ) и техническим (по минерализации воды, общей жесткости и содержанию в воде взвешенных веществ, содержания марганца, железа и активности водорода) критериям.

Исследованиями установлено, что по опасности ирригационного засоления почв оросительные воды такого качества соответствуют I классу качества воды и пригодны для систем капельного орошения без ограничений. Кроме того, на основании комплексной оценки показателей ( $\mathrm{pH}$, токсической щелочности, щелочности от нормальных карбонатов, величины отношения суммы щелочных катионов натрия и калия к сумме всех катионов, с учетом гранулометрического состава почв и их буферности) оросительные воды соответствуют I классу качества воды и пригодны для систем капельного орошения без ограничений. По экологическим критериям оросительные воды Турунчука по содержанию микроэлементов и тяжелых металлов соответствуют I классу качества воды и не могут оказывать негативное влияние на почвы и сельскохозяйственные культуры.

Оценивание пригодности воды по степени влияния её на элементы систем капельного орошения выполнено с учетом возможности предотвращения их коррозии, заилению, биозарастания, которые происходят в результате постепенного накопления в них взвешенных наносов минерального и органического происхождения, отложений солей и продуктов жизнедеятельности микроорганизмов. Исследованием установлено, что поверхностные воды р. Турунчук по степени влияния на узлы и элементы трубопроводной сети пригодны для капельного орошения без ограничений.
\end{abstract}

Ключевые слова: капельное орошение, агрономические, экологические, технические критерии качества воды.

Стаття надійшла 25.02.2019 